\title{
Ophthalmologic findings in newborns of women with Zika virus infection during pregnancy: A case series
}

\section{Hallazgos oftalmológicos en recién nacidos de mujeres con Zika durante la gestación: Serie de casos}

\author{
Adriana Dávila-Camargo ${ }^{1 *}$, Jaime J. Durán-Nah² and Alfonso Dupinet-Sánchez ${ }^{1}$
}

${ }^{1}$ Department of Ophthalmology, Hospital General Regional No. 12, Mexican Institute of Social Security; ${ }^{2}$ Hospital General O'Horán, Servicios de Salud de Yucatán, Mérida, Yucatán, México

\begin{abstract}
Objective: Describe ocular findings in newborns of women with the Zika virus (ZIKV) infection during gestation. Materials and Methods: From November 2016 to March 2017, 26 newborns of women with ZIKV infection, confirmed with a reverse transcription polymerase chain reaction test, were examined at the Ophthalmology Department of a General Hospital belonging to the Mexican Institute of Social Security in Merida, Yucatan, Mexico. Results: Maternal gestational age at the time of ZIKV diagnosis averaged $29.1 \pm 6.9$ weeks (95\% confidence interval 26.3-31.9). One case (3.8\%) was diagnosed during the first trimester and 15 cases (57.7\%) during the third trimester of gestation. 16 newborns (61.5\%) were male. Neither microcephaly nor abnormal ocular abnormalities were found in any newborn. Conclusions: No microcephaly or ocular abnormalities were found in our case series, perhaps due to a previous antigenic exposure to flavivirus diseases such as dengue in the Yucatan Peninsula, to infection mostly during the third trimester, or to the short period of time that the ZIKV has been in our country. Nonetheless, ophthalmologists should be aware of the possible ophthalmological complications associated with ZIKV.
\end{abstract}

Key words: Zika virus infection. Microcephaly. Arboviruses.

\section{Resumen}

Objetivo: Describir hallazgos oculares en recién nacidos (RN) de mujeres con infección por zika durante la gestación. Pacientes y Métodos: Entre noviembre de 2016 y marzo de 2017, veintiséis RN de mujeres que tuvieron infección de Zika confirmada por PCR fueron examinados en el departamento de Oftalmología de un Hospital del Instituto Mexicano del Seguro Social en Mérida, México. Resultados: La edad gestacional al diagnóstico fue de $29.1 \pm 6.9$ semanas, una gestante (3.8\%) tuvo Zika durante el primer trimestre de la gestación. Ningún RN tenía anormalidades oculares. Conclusiones: No encontramos anormalidades oftalmológicas probablemente debido a una exposición antigénica previa a flavivirus (Dengue), a que la infección fue en su mayoría durante el tercer trimestre o debido al corto tiempo que tiene el Zika en Yucatán. No obstante, los oftalmólogos deben estar conscientes de las posibles complicaciones oftalmológicas asociadas con el virus Zika.

Palabras clave: Virus Zika. Mirocefalia. Arbovirus.

Correspondence:

Adriana Dávila-Camargo

Chimalpopoca, 14

Col. Obrera

Date of reception: 30-08-2017

C.P. 06800, Mexico City, Mexico

Date of acceptance: 22-11-2017

DOI: 10.24875/RMOE.M18000001
Available online: 16-07-2018

Rev Mex Oftalmol (Eng). 2018;92(4):159-162 www.rmo.com.mx

2604-1731/@ 2018 Sociedad Mexicana de Oftalmología. Published by Permanyer México SA de CV. This is an Open Access article under the CC BY-NC-ND license (http://creativecommons.org/licenses/by-nc-nd/4.0/). 


\section{Introduction}

According to epidemiological data, the first Zika virus (ZIKV) infection in Mexico was identified in October 2015. By January 2017, more autochthonous Zika cases were confirmed in at least 25 states, and by March 2017, Mexican health authorities had reported 4390 cases of ZIKV infection in pregnant women, with the state of Yucatán having the second highest incidence rate (642 cases) $)^{1}$.

Previous reports suggest that ZIKV infection can be vertically transmitted from the mother to the fetus during pregnancy, having been described a congenital Zika syndrome (CZS), particularly when the infection occurs during the first trimester ${ }^{2,3}$. As part of its diagnostic criteria ${ }^{4}$, CZS is characterized by microcephaly and ocular abnormalities such as focal pigment mottling, chorioretinal atrophy, optic nerve hypoplasia, and severe cupping of the optic disk ${ }^{5}$. In Mexico, five cases of CZS had been identified as of March $2017^{6}$.

The epidemiological data of the ocular findings in newborns with CZS are still an undergoing investigation $^{7,8}$. In CZS cases from Mexico, microcephaly was documented, but no ocular abnormalities were described $^{5}$. Studies from Ventura et al. in Brazil describe a probable association between microcephaly and ocular abnormalities ${ }^{9}$, but de Paula Freitas et al., in Brazil as well, described that as many as $65 \%$ of newborns with microcephaly did not have ocular anomalies ${ }^{10}$. To the best of our knowledge, there are no available data regarding the ocular abnormalities of Zika newborns who did not present microcephaly.

Since the Yucatan Peninsula in México is considered an endemic zone for ZIKV affecting pregnant women, we believe it is valuable and timely to describe ocular findings from a case series of newborns of ZIKV-infected women.

\section{Materials and methods}

From November 2016 to March 2017, 26 newborns of mothers with ZIKV infection during pregnancy confirmed by a reverse transcriptase polymerase chain reaction (PCR) test (Instituto de Diagnóstico y Referencia Epidemiológicos, Mexico City $)^{11,12}$, were examined by the same ophthalmologists (A.D./A.D.) with a Welch Allyn 125 Binocular Indirect Ophthalmoscope and a 20 D Volk Indirect BIO Lens, at the Ophthalmology Department of a General Hospital belonging to the Mexican Institute of Social Security in Merida, Yucatan, Mexico. As part of the neonatal screening test, TORCH panel (toxoplasmosis, cytomegalovirus infection, rubella virus infection, syphilis infection, and human immunodeficiency virus infection), cephalic perimeter, transfontanelar ultrasound, and auditory screening tests were also completed and reported by the pediatric, radiology, and otorhinolaryngology department.

The analyzed variables were gender, maternal gestational age at the time of ZIKV infection diagnosis, days of birth at the time of ophthalmology examination, head abnormalities (especially microcephaly) and findings of the ophthalmological examination. Microcephaly, described as head circumference at birth less than the $3^{\text {rd }}$ percentile for gestational age and $\operatorname{sex}^{13}$, was examined and reported previously in a pediatric examination. Descriptive statistics were used to report results.

\section{Results}

A total of 55 newborns from mothers who had a probable diagnosis of ZIKV infection during pregnancy were examined, although 28 newborns were excluded because maternal ZIKV infection was not PCR confirmed. One case was PCR positive to the dengue virus, so it was also excluded from analysis. Of the 26 cases, remaining of mothers with PCR-confirmed ZIKV infection, 52 newborns eyes were examined.

The clinical ZIKV symptoms of pregnant women were reported at a gestational age that ranged from 12 to 38 weeks, with an average of $29.1 \pm 6.9$ weeks (95\% confidence interval 26.3-31.9). By trimester of gestation, 1 case $(3.8 \%)$ was diagnosed during the first trimester, 10 cases (38.5\%) during the second trimester, and 15 cases $(57.7 \%)$ during the third trimester. By gender, 16 (61.5\%) newborns were male. Microcephaly was not reported in any case. The newborn's age at the time of the ophthalmological examination ranged from 2 to 154 days of birth (median 15 days, $25-75 \%$ interquartile ranges, $5.7-36$ days). The only abnormal ocular finding was a small, peripapillary intraretinal hemorrhage in a 4-day-old male newborn with a medical history of forceps delivery, whose mother had PCR-confirmed ZIKV at week 30 of gestation.

\section{Discussion}

In the 26 infants that were examined, none of the ocular abnormalities related to ZIKV infection were identified ${ }^{6-8}$. The intraretinal hemorrhage case we found was not considered to be associated with ZIKV 
infection because it was most likely due to the obstetric procedure by which the newborn was obtained. However, Miranda et al. ${ }^{5}$ have reported scattered sub-retinal hemorrhages external to the macula, as a hallmark associated to ZIKV infection, making hemorrhage from ZIKV infection a possibility.

Primary ocular complications associated with ZIKV infection appear not to be newborn-specific since they have also been documented in adults ${ }^{14}$. Previous studies have found that $34.5 \%$ of infants with CZS have ophthalmic abnormalities ${ }^{6}$. In contrast, taking into consideration that our case series was larger than those previously described ${ }^{6-8}$, we believe it is interesting to analyze why we did not find any ocular abnormality. Explanations could be several and related in part to the presence or absence of any risk factors in each affected population.

Risk factors for ocular abnormalities associated with ZIKV infection appear to include infants whose mothers were infected during the first trimester of pregnancy and when microcephaly is present ${ }^{6-8,15}$. The incidence of infants with ocular abnormalities associated with ZIKV infection may be less frequent or even absent when women contracted ZIKV during the second or the third trimester of pregnancy ${ }^{10}$. On the other hand, ocular anomalies have also been reported in a patient born at term, with no microcephaly9.

In our study, $96 \%$ of mothers acquired ZIKV infection during the second and third trimester of gestation, a period in which organogenesis is complete, so the deleterious effects of $\mathrm{ZIKV}^{16}$ could be attenuated or even absent, which could explain the absence of ocular abnormalities ${ }^{17}$. Most importantly, some patients including ours may have some type of immunologic resistance or protection against the deleterious effects the ZIKV has onto the brain tissue and its related structures such as the retina and the ophthalmic nerves ${ }^{18}$.

In supporting this idea, a cross-reaction protective effect with antibodies against the ZIKV triggered by a previous dengue virus infection is not impossible ${ }^{19}$ since our pregnant women are living in a flavivirus endemic area such as the Yucatan Peninsula, so previous exposures to such or other flaviviruses could be protecting them. Finally, the absence of microcephaly and ocular abnormalities in our cases could be due to underreporting of cases, or even due to the seasonal behavior the ZIKV infection outbreak has had, so the time elapsed since the Zika outbreak began in the Yucatan Peninsula has not been long enough to allow us to see the true magnitude of the problem.

\section{Conclusions}

No ocular abnormalities were found in newborns referred to our service as part of a screening for CZS. Factors that can explain our findings include the trimester of gestation at the time of diagnosis, previous exposure to other flavivirus, underreporting, and the short time the ZIKV has been in our region. In high-transmission settings such as the state of Yucatan, Mexico, ophthalmologists should be aware to identify earlier, congenital ZIKV-associated ophthalmologic complications.

\section{Acknowledgments}

We gratefully recognize the medical authorities from the Hospital General No. 12, for all the facilities we had needed for carrying out our medical investigation.

\section{Ethical disclosures}

Protection of human and animal subjects: The authors declare that no experiments were performed on humans or animals for this study.

Confidentiality of data: The authors declare that they have followed the protocols of their work center on the publication of patient data.

Right to privacy and informed consent: The authors declare that no identifiable patient data appear in this article.

\section{Funding}

The author(s) received no specific funding for this work.

\section{Conflicts of interest}

The authors declare no conflicts of interest.

\section{References}

1. WHO. Zika Epidemiological Report. Mexico, Pan American Health Organization/World Health Organization. Zika-Epidemiological Report Mexico. March 2017. Washington, DC: PAHO, WHO; 2017. Available from: http:// www.paho.org/hq/index.php?option=com_docman\&task=doc_view\&gi$d=35106 \&$ Itemid=270. [Consulted 15 July 2017]

2. Calvet G, Aguiar RS, Melo ASO, et al. Detection and sequencing of Zika virus from amniotic fluid of fetuses with microcephaly in Brazil: a case study. Lancet Infect Dis. 2016:16:653-60.

3. Oliveira Melo AS, Malinger G, Ximenes R, Szejnfeld PO, Alves Sampaio S, Bispo de Filippis AM. Zika virus intrauterine infection causes fetal brain abnormality and microcephaly: tip of the iceberg? Ultrasound Obstet Gynecol. 2016;47:6-7.

4. Costello A, Dua T, Duran P, et al. Defining the syndrome associated with congenital Zika virus infection. Bull World Health Organ. 2016:94:406-406A

5. Miranda $H A 2^{\text {nd }}$, Costa $M C$, Frazão $M A$, Simão N, Franchischini $S$, Moshfeghi DM. expanded spectrum of congenital ocular findings in mi- 
Rev Mex Oftalmol (Eng). 2018;92

crocephaly with presumed Zika infection. Ophthalmology. 2016;123:1788-94.

6. Secretaría de Salud. Dirección General de Epidemiología. Desglose de casos de Síndrome Congénito Asociado a Zika. Abril; 2017. Available from: http://www.gob.mx/salud/documentos/desglose-de-casos-de-sindrome-congenito-asociado-a-zika. [Consulted 15 July 2017].

7. Ventura CV, Maia M, Ventura BV, et al. Ophthalmological findings in infants with microcephaly and presumable intra-uterus Zika virus infection. Arq Bras Oftalmol. 2016;79:1-3.

8. Yepez JB, Murati FA, Pettito M, et al. Ophthalmic manifestations of congenital zika syndrome in Colombia and Venezuela. JAMA Ophthalmol. 2017;135:440-5.

9. Ventura CV, Maia M, Dias N, Ventura LO, Belfort R Jr. Zika: neurologica and ocular findings in infant without microcephaly. Lancet. 2016:387:2502.

10. de Paula Freitas B, de Oliveira Dias JR, Prazeres J, et al. Ocular findings in infants with microcephaly associated with presumed zika virus congenital infection in salvador, Brazil. JAMA Ophthalmol. 2016.

11. Lineamientos Para la Vigilancia Epidemiológica y Diagnóstico Por Laboratorio de Infección por Virus Zika, Secretaría de Salud, Mayo; 2016 Versión 3.0. Available from: https://www.gob.mx/cms/uploads/attachment/ file/121722/lineamientos_ve_y_lab_virus_zika.pdf. [Consulted 15 July 2017].

12. Lineamientos Estandarizados Para la Vigilancia Epidemiológica y Diag nóstico por Laboratorio de Infección por Virus Zika. Dirección Genera de Epidemiología, Secretaria de Salud, México, Diciembre; 2015. Avai- lable from: https://www.gob.mx/cms/uploads/attachment/file/207354/lineamientos_ve_y_lab_virus_zika.pdf. [Consulted 15 July 2017].

3. Congenital Microcephaly Case Definitions. Centers for Disease Contro and Prevention, 20 Octobe; 2016. Available from: http://www.cdc.gov/ zika/public-health-partners/microcephaly-case-definitions.htmP. [Consulted 15 July 2017].

14. Kodati S, Palmore TN, Spellman FA, Cunningham D, Weistrop B, Sen HN. Bilateral posterior uveitis associated with Zika virus infection. Lancet. 2017;389:125-6.

15. Ventura CV, Maia M, Travassos SB, et al. Risk factors associated with the ophthalmoscopic findings identified in infants with presumed Zika virus congenital infection JAMA Ophthalmol. 2016;134:912-8.

16. Retallack H, Di Lullo $E$, Arias $C$, et al. Zika virus cell tropism in the developing human brain and inhibition by azithromycin. Proc Natl Acad Sci USA. 2016:113:14408-13.

17. Cauchemez S, Besnard M, Bompard P, et al. Association between Zika virus and microcephaly in French Polynesia, 2013-2015: a retrospective study. Lancet. 2016;387:2125-32.

18. Li C, Deng YQ, Wang S, et al. 25-Hydroxycholesterol protects host against Zika virus infection and its associated microcephaly in a mouse model. Immunity. 2017:46:446-56.

19. Dejnirattisai W, Supasa P, Wongwiwat W, et al. Dengue virus sero-cross-reactivity drives antibody-dependent enhancement of infection with zika virus. Nat Immunol. 2016;17:1102-8. 